\title{
Investigation of Copper Corrosion Behavior in Various Sulfide Solutions
}

\author{
Kexin Liang a , Yunfei Xu ${ }^{\mathrm{b}}$, Quan Lu ${ }^{\mathrm{c}}$, Shenghan Zhang ${ }^{\mathrm{d}}$ and Yu Tan ${ }^{\mathrm{e}}$ \\ Department of Environment Science and Engineering, North China Electric Power University, \\ Yonghua North Street 619\#, Baoding 071003, China. \\ akexin91802@163.com, b654526855@qq.com, ${ }^{c} 1054725193 @ q q . c o m,{ }^{d}$ zhang-shenghan@163.com, \\ elucifertan@163.com
}

Keywords: $\mathrm{Cu}$, corrosion, sulfide solution.

\begin{abstract}
Copper, works as a protector of used fuel rods of nuclear power plant, can suffer most corrosion for its properties. While the copper, once reacting with sulfate/sulfide solutions from oil when buried deeply, may involve new corrosion problem. In this paper, mass loss experiments and potentiodynamic polarization are employed to investigate the corrosion behavior of copper in sulfide/sulfate solutions. The results of the mass loss indicated that when the temperature is $60^{\circ} \mathrm{C}$, the corrosion rates of copper decrease with the increase of concentration of $\mathrm{Na}_{2} \mathrm{~S}$ and $\mathrm{Na}_{2} \mathrm{SO}_{3}$. The potentiodynamic polarization of copper indicated that under the same temperature, the corrosion current densities of pure copper in $\mathrm{Na}_{2} \mathrm{~S}, \mathrm{NaCl}$ and $\mathrm{Na}_{2} \mathrm{SO}_{4}$ aqueous solutions increased with the increase of solute concentrations. Keeping the concentration of each solution constant, the corrosion rate increases quickly with the rise of temperature. It should be highlighted that copper corrodes very fast in the $\mathrm{Na}_{2} \mathrm{~S}$ solution among these solutions.
\end{abstract}

\section{Introduction}

The copper is a metal which plays wide applications for its good anticorrosion properties. Copper is resistant toward the influence of atmosphere and many chemicals, however, it is known that in aggressive media it is susceptible to corrosion [1]. One of the uses of copper is as a protector of used fuel rods of nuclear power plant and buried in deep soil. Since the copper cladding is the only barrier shielding the radioactive nuclide, the corrosion of copper has been widely studied [1-10]. The copper plays high thermodynamic stability at room temperature, whereas at high temperatures, copper in corrosive mediums encounters serious corrosion. It has been reported that the copper reacts with sulfide extractives, such as pyrite, from the soil [11]. The sulfide corrosion of copper damaged the mechanical structure of the cladding for nuclear wastes. In addition, water and salts (such as $\mathrm{NaCl}$, $\mathrm{Na}_{2} \mathrm{SO}_{4}$ ) in the soil will also accelerate the corrosion process of copper. The rich content of $\mathrm{Cl}^{-}$and $\mathrm{SO}_{4}{ }^{2-}$ in the soil will increase the rate of copper corrosion [12]. Therefore, the research of the corrosion behavior of copper in sulfide aqueous solutions, besides sulfate and chloride solutions, is urgent considering the protection of copper cladding buried in the soil.

The mechanism of copper corrosion in various sulfide solutions was studied. Under the condition of deoxidizing, the copper corrosion with sulfide aqueous solutions usually plays as electrochemical corrosion. With the $\mathrm{pH}$ of sulfide aqueous solutions increasing, the corrosion speed of system can be reduced. At the very beginning of copper immersing in the sulfide aqueous solution, a single layer of dense $\mathrm{Cu}_{2} \mathrm{~S}$ sulfide film formed on copper surface [7, 13-14]. The growth of sulfide film follows the dynamic mechanism of Parabola. With the extension of soaking time, sulfide film fractures, then falls off and grows again [15].

In this paper, the corrosion behavior of pure copper in sulfur-containing solution was investigated by chemical and electrochemical experiments. The copper corrosion behavior in sulfide aqueous solution was explained with a new mechanism with corrosion product analysis. Our results would be useful in the design and development of new copper corrosion inhibitors. 


\section{Experimental methods}

\subsection{Mass loss method to investigate the corrosion rates of $\mathrm{Cu}$.}

The 'pure copper' (oxygen free, $>99.5 \%$ mass) sheets of $40.0 \mathrm{~mm} \times 10.0 \mathrm{~mm}$ were prepared by mechanical grinding and polishing, followed by ultrasonic baths in acetone and alcohol for 10 minutes, respectively. After rinsing in deionized water, the copper specimens were blow-dried and weighted. These copper specimens were corroded at different concentrations of $\mathrm{Na}_{2} \mathrm{~S}$ and $\mathrm{Na}_{2} \mathrm{SO}_{3}$ solutions, pure water and sublimed sulfur powder at $60{ }^{\circ} \mathrm{C}$ as a simulated underground temperature for 7 days (168 hours) as 'mass loss method' to investigate the corrosion rates. After being taken out, the specimens were washed with distilled water, blow-dried and weighted again. Comparing the weight losses of these copper specimens before and after corrosion, the corrosion rates of copper in various solutions and solid matrixes were calculated.

\subsection{Potentiodynamic polarization.}

The specimens employed for potentiodynamic polarization measurements are pure copper (> 99.5\%) rods of $10.0 \mathrm{~mm}$ diameter with a wire lead sealed one side by epoxy resin. The measurements were conducted in $\mathrm{NaCl}, \mathrm{Na}_{2} \mathrm{SO}_{3}, \mathrm{Na}_{2} \mathrm{SO}_{4}$ and $\mathrm{Na}_{2} \mathrm{~S}$ solutions in various concentrations $(0.1,0.01$ and $0.001 \mathrm{M})$ and at various temperatures $\left(20,40,60\right.$ and $\left.80^{\circ} \mathrm{C}\right)$. The above sealed copper rods were used as working electrodes while a saturated calomel electrode (SCE) was used as the reference electrode and Pt sheet was the auxiliary electrode. Potentiodynamic polarizations were tested using CHI650D electrochemical work station, with a potential range from about $0.2 \mathrm{~V}$ lower than the open circle potential (OCP) to the full anodic passivation state with a scanning rate of $1.0 \mathrm{mV} / \mathrm{s}$. Before the test, the prepared specimens were immersed into various solutions for 10 mins to get steady OCPs.

\section{Results and Discussion}

\subsection{Mass loss method.}

Fig. 1 showed the mass loss of copper in various sulfate/sulfide-containing solutions, besides pure water and sublimed sulfur powder at constant temperature of $60^{\circ} \mathrm{C}$ for 7 days. First, the corrosion of copper in $\mathrm{S}$ produced a hard and brittle surface. There is a surprising weight loss rather than increase of copper in S powders. Then in pure water, copper corroded at a certain rate as shown in Fig. 1 at $60^{\circ} \mathrm{C}$ with slight weight gaining. In $\mathrm{NaCl}$ solution, when the concentration is very high at $0.1 \mathrm{M}$, the copper suffered heave mass loss corrosion. While in very low concentration at 0.01 and $0.001 \mathrm{M}$, the mass loss results of copper are very low. The copper samples played the same corrosion behavior in $\mathrm{Na}_{2} \mathrm{SO}_{4}$ solution. In $0.001 \mathrm{M} \mathrm{Na} 2 \mathrm{~S}$ solution, $\mathrm{Cu}_{2} \mathrm{~S}$ produced. With the increasing of $\mathrm{Na}_{2} \mathrm{~S}$ concentration to $0.1 \mathrm{M}$, the product changed into $\mathrm{CuS}$. As $\mathrm{CuS}$ is more resistant to corrosion than $\mathrm{Cu}_{2} \mathrm{~S}$, the increasing concentration of $\mathrm{Na}_{2} \mathrm{~S}$ causes the corrosion rate shrinking. Therefore, the copper corroded most slowly in $0.1 \mathrm{M} \mathrm{Na}_{2} \mathrm{~S}$ solution. In contrast, $\mathrm{Na}_{2} \mathrm{SO}_{3}$ plays as a reductive agent and the higher concentrations of $\mathrm{Na}_{2} \mathrm{SO}_{3}$ inhibit the corrosion of copper induced by oxygen. So the corrosion rate of copper in $0.1 \mathrm{M}$ $\mathrm{Na}_{2} \mathrm{SO}_{3}$ is also smaller than that of $0.001 \mathrm{M}$.

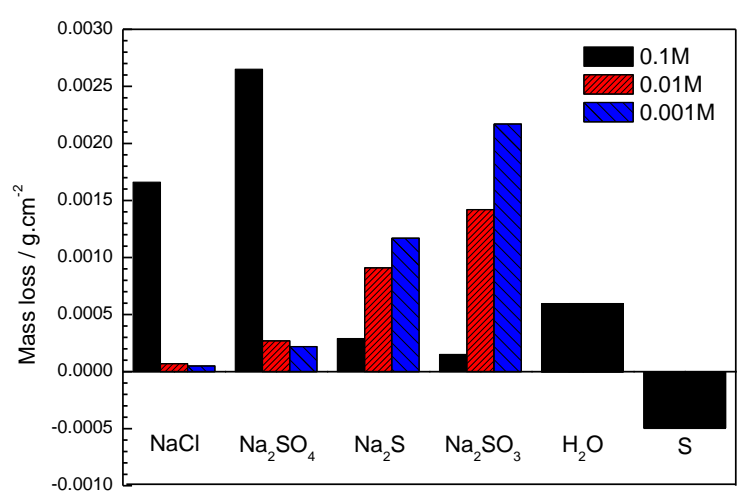

Fig. 1 Mass loss of the copper sheets in different matrixes with varied concentrations at $60^{\circ} \mathrm{C}$ for 7 days (the concentrations for water and $\mathrm{S}$ have no meaning). 


\subsection{Potentiodynamic polarization}

Fig. 2 shows the polarization plots of copper in $\mathrm{Na}_{2} \mathrm{SO}_{4}, \mathrm{NaCl}, \mathrm{Na}_{2} \mathrm{SO}_{3}$ and $\mathrm{Na}_{2} \mathrm{~S}$ solutions at $60{ }^{\circ} \mathrm{C}$. As shown in Fig.2 (a), $\mathrm{Na}_{2} \mathrm{SO}_{4}$ is a kind of ineffective corrosion solution for copper and only play the role of supporting electrolyte. So, the differences of corrosion potential $\left(\mathrm{E}_{\text {corr }}\right)$ in $\mathrm{Na}_{2} \mathrm{SO}_{4}$ aqueous solution are not obvious except for that of in $0.1 \mathrm{M}$. High concentration of sulfate decreased $\mathrm{E}_{\text {corr }}$ for the copper corroded in such a high ineffective salt solution.
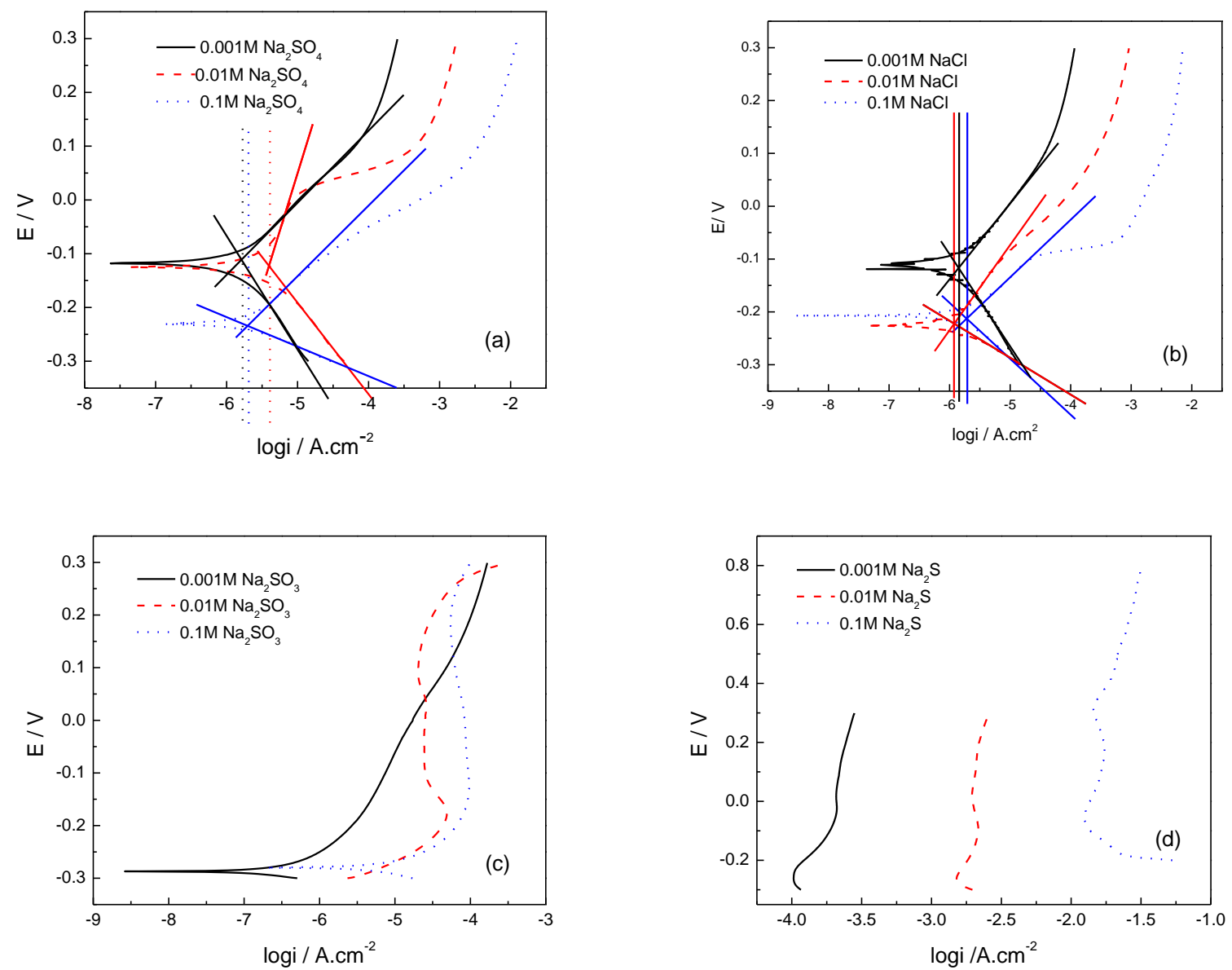

Fig.2 Potentiodynamic polarization plots of copper in $\mathrm{Na} 2 \mathrm{SO} 4, \mathrm{NaCl}, \mathrm{Na} 2 \mathrm{SO} 3$ and $\mathrm{Na} 2 \mathrm{~S}$ solutions for different concentration of $0.1,0.01$ and $0.001 \mathrm{M}$ at $60{ }^{\circ} \mathrm{C}$ with scan rate of $1 \mathrm{mV} . \mathrm{s}-1$.

The corrosion parameters such as $\mathrm{E}_{\text {corr }}$, corrosion current density $\left(\mathrm{I}_{\text {corr }}\right)$ and corrosion resistance $\left(\mathrm{R}_{\mathrm{P}}\right.$ ), in addition to the Tafel (cathodic, $\beta_{\mathrm{c}}$, and anodic, $\beta_{\mathrm{a}}$ ) slopes from Fig. 2 are listed in Table.1. The values of $\mathrm{E}_{\text {corr }}$ and $\mathrm{I}_{\text {corr }}$ were evaluated from the cathodic and anodic curve by CHI Instrument Software. The values of $\beta_{\mathrm{c}}$ and $\beta_{\mathrm{a}}$ were determined after at least $50 \mathrm{mV}$ away from $\mathrm{E}_{\mathrm{corr}}$ and at least one decade of Icorr. The $\mathrm{R}_{\mathrm{p}}$ values from the different copper corrosion were calculated from the Stern-Geary equation [16] using parameters listed in Table. 1 as below:

$$
\mathrm{R}_{\mathrm{p}}=\frac{1}{I_{\text {corr }}}\left(\frac{\beta_{0} \beta_{a}}{2.3\left(\beta_{e}+\beta_{n}\right)}\right)
$$

With the increasing of anodic potential, $\mathrm{I}_{\text {corr }}$ at high potential regularly increases with the increasing of the concentration. As shown in Fig.2(b), with the increase of concentration of $\mathrm{NaCl}$ solution from 0.001 to $0.01 \mathrm{M}, \mathrm{E}_{\text {corr }}$ of copper significantly decreased. Unlike iron group materials, copper in $\mathrm{NaCl}$ solution does not show any obvious pitting corrosion phenomenon. This may be due to the surface treatment of copper failed to form effective passivation layer and $\mathrm{Cl}^{-}$is not effectively corrosive toward copper. So when the concentration of $\mathrm{NaCl}$ solution increased from 0.01 to $0.1 \mathrm{M}$, the change of $\mathrm{E}_{\text {corr }}$ is not significant (even lower). As shown in Fig.2(a), with the increasing of concentration of $\mathrm{Na}_{2} \mathrm{SO}_{4}$ solution, $\mathrm{E}_{\text {corr }}$ shows an obvious drop, and $\mathrm{I}_{\text {corr }}$ density changes little at the higher part of anode polarization voltage 
. The possible reason is that the $\mathrm{Na}_{2} \mathrm{SO}_{4}$ plays only a positive site at the surface of copper electrode. And high concentration of $\mathrm{Na}_{2} \mathrm{SO}_{4}$ lowers the corrosion resistance at the interface between electrode and solution. When the copper electrode deeps into $\mathrm{Na}_{2} \mathrm{SO}_{3}$ solution as Fig.2(c), the $\mathrm{E}_{\text {corr }}$ did not change much during the concentration increasing. The possible reason is that $\mathrm{Na}_{2} \mathrm{SO}_{3}$ plays as a reducing agent, so high levels of $\mathrm{Na}_{2} \mathrm{SO}_{3}$ inhibit the corrosion of copper from oxygen. As shown in Fig.2(d), for the lower concentration of $\mathrm{Na}_{2} \mathrm{~S}$ solution, the polarization plot of copper in sodium sulfide can be obtained. In high concentration of $\mathrm{Na}_{2} \mathrm{~S}$ solution, the polarization plot is not typical, and the current density is very large. This may be caused by $\mathrm{S}^{2-}$ reacting with copper which produces $\mathrm{CuS}$. It should be pointed out that when the copper immersed into $\mathrm{Na}_{2} \mathrm{~S}$ solution, the reaction/corrosion started. So no steady OCP or a typical polarization plot can be obtained.

At 20, 40 and $80{ }^{\circ} \mathrm{C}$, the polarization plots of copper in $\mathrm{Na}_{2} \mathrm{SO}_{4}, \mathrm{NaCl}, \mathrm{Na}_{2} \mathrm{SO}_{3}, \mathrm{Na}_{2} \mathrm{~S}$ aqueous solutions indicated nearly similar corrosion laws as that at $60{ }^{\circ} \mathrm{C}$.

The polarization plot shows that $\mathrm{Na}_{2} \mathrm{SO}_{3}$ solution as reducing agent may protect the copper from oxidation, which has a certain effect on the corrosion resistance of copper. The polarization plot of $\mathrm{Na}_{2} \mathrm{~S}$ solution is distinct from the other solutions because of the violent corrosive reaction of copper with $\mathrm{S}^{2-}$. Fig. 3 shows the potentiodynamic polarization plots of copper in $\mathrm{Na}_{2} \mathrm{~S}, \mathrm{Na}_{2} \mathrm{SO}_{3}, \mathrm{Na}_{2} \mathrm{SO}_{4}$ and $\mathrm{NaCl}$ solutions of $0.1 \mathrm{M}$ at different temperatures. In Fig.3(a), there is no clear cathodic to anodic polarization change shown from this figure because of the strong corrosion when copper was immersed in $\mathrm{S}^{2-}$ aqueous solution. Fig.3(a) shows that the corrosion current of copper in $\mathrm{Na}_{2} \mathrm{~S}$ solution significantly increased with the rise of temperature. The fitting results listed in Table. 2 also indicated the corrosion behavior of copper in various solutions. Such as in $\mathrm{NaCl}$ solution, the corrosion resistance $R_{P}$ reduced as temperature increasing from 20 to $80^{\circ} \mathrm{C}$. As shown in Figs.3(b), (c) and (d), the corrosion current of copper in $\mathrm{Na}_{2} \mathrm{SO}_{3}, \mathrm{Na}_{2} \mathrm{SO}_{4}$ and $\mathrm{NaCl}$ solutions increased with the increase of temperature slightly. So, with the increasing of solution temperature, corrosion rates of copper in $\mathrm{Na}_{2} \mathrm{~S}$, $\mathrm{Na}_{2} \mathrm{SO}_{3}, \mathrm{Na}_{2} \mathrm{SO}_{4}$ and $\mathrm{NaCl}$ solutions of $0.1 \mathrm{M}$ become larger.

It is investigated that there are two type of corrosion production for copper in the oxygen environments: $\mathrm{Cu}_{2} \mathrm{O}$ (cuprous oxide) and $\mathrm{CuO}$ (cupric oxide)[20]. The amount of both oxides plays an essential effect on the growth of copper corrosion. The scales of $\mathrm{Cu}_{2} \mathrm{O}$ and $\mathrm{CuO}$ formed on $\mathrm{Cu}$ in the oxygen environments and at elevated temperature depend on the thermodynamic stability of the oxides.

Comparison of the opposite trends of copper corrosion in $\mathrm{Na}_{2} \mathrm{~S}$ solution by immersing and potentiodynamic polarization, the former one suggested a protected layer when the copper specimen was immersed and this layer indicated a property to protect copper for further corrosion. So for the mass loss experiment, the copper corroded less in a higher concentration solution of $\mathrm{Na}_{2} \mathrm{~S}$. When the copper specimen was immersed in $\mathrm{Na}_{2} \mathrm{~S}$ solution with electrochemical cell connection, the corrosion product could not protect the copper. So in the potentiodynamic polarization experiment, the copper corrosion was enhanced when the concentration of $\mathrm{Na}_{2} \mathrm{~S}$ increased.
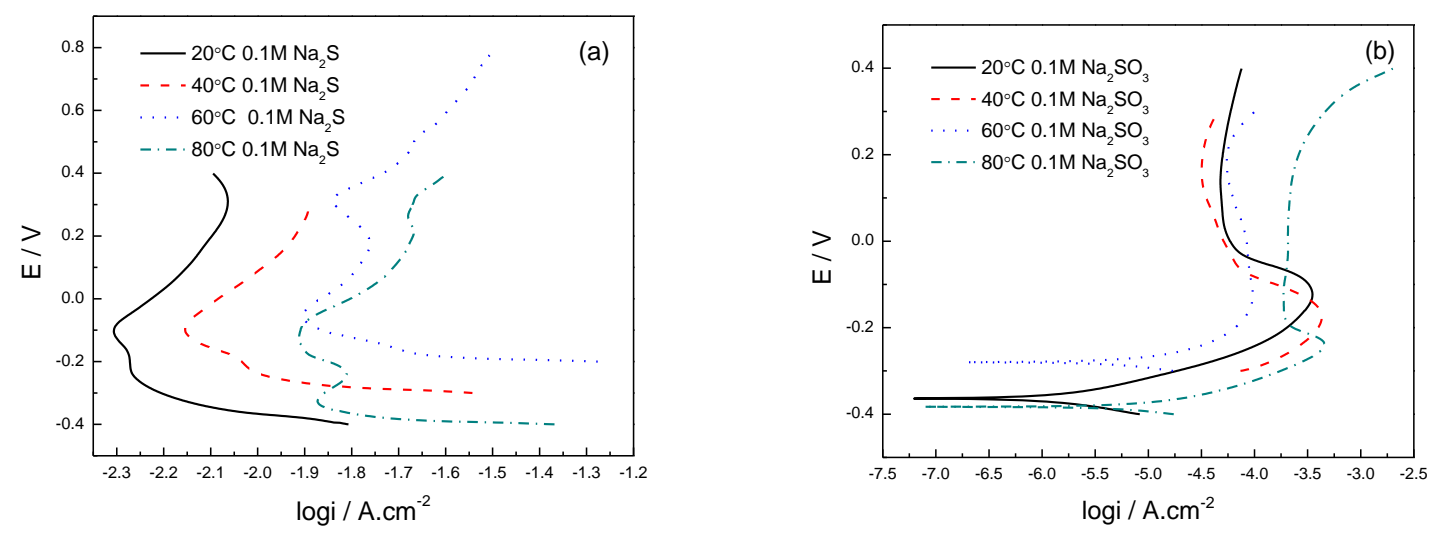

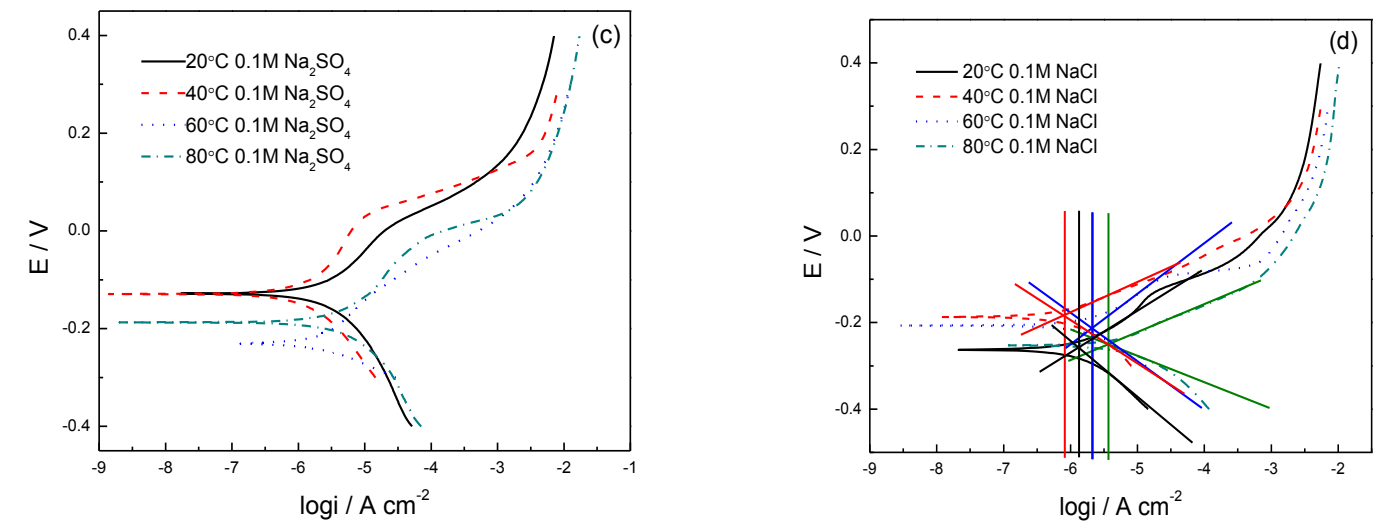

Fig.3 Potentiodynamic polarization plots of copper in $\mathrm{Na} 2 \mathrm{~S}, \mathrm{Na} 2 \mathrm{SO} 3, \mathrm{Na} 2 \mathrm{SO} 4$ and $\mathrm{NaCl}$ solutions of $0.1 \mathrm{M}$ at different temperatures of $20,40,60$ and $80^{\circ} \mathrm{C}$ with scan rate of $1 \mathrm{mV} . s-1$.

\section{Conclusion}

The mass loss results show that when the temperature was $60^{\circ} \mathrm{C}$, with the increasing of concentration of $\mathrm{Na}_{2} \mathrm{~S}$ and $\mathrm{Na}_{2} \mathrm{SO}_{3}$, the corrosion rate of copper decreased.

The potentiodynamic polarization plots indicated that at the same temperature, corrosion current of copper in $\mathrm{Na}_{2} \mathrm{~S}, \mathrm{NaCl}$ and $\mathrm{Na}_{2} \mathrm{SO}_{4}$ solutions increased with the increasing of concentration. Under the same concentration in sulfide solutions, with the rise of temperature, corrosion current increased quickly.

\section{Acknowledgments}

This work is supported by the Fundamental Research Funds for the Central Universities.

\section{References}

[1]. Antonijević M M, Petrovic M B. Copper Corrosion Inhibitors. A review. Int. J. Electrochem. Sci. Vol. 3 (2008) p. 1-28.

[2]. Rosborg B, Pan J, Leygraf C. Tafel slopes used in monitoring of $\mathrm{Cu}$ corrosion in a bentonite/groundwater environment. Corros. Sci. Vol. 47 (2005) p. 3267-3279.

[3]. Rosborg B, Pan J. An electrochemical impedance spectroscopy study of $\mathrm{Cu}$ in a bentonite/saline groundwater environment. Electrochim. Acta. Vol. 53 (2008) p. 7556-7564.

[4]. Bojinov M, Betova I, Lilja C. A mechanism of interaction of $\mathrm{Cu}$ with a deoxygenated neutral aqueous solution. Corros. Sci. Vol. 52 (2010) p. 2917-2927.

[5]. Betova I, Beverskog B, Bojinov M, et. Al. Corrosion of $\mathrm{Cu}$ in nuclear waste repository conditions. Electrochem. Solid-State Lett. Vol. 6 (2003) p. B19-B22.

[6]. Srivastava A, Balasubramaniam R. Electrochemical impedance spectroscopy study of surface films formed on $\mathrm{Cu}$ in aqueous environments. Mater. Corrosion. Vol. 56 (2005) p. 611-618.

[7]. Chen J, Qin Z, Shoesmith D W. Long-term corrosion of Cu in a dilute anaerobic sulfide solution. Electrochim. Acta. Vol. 56 (2011) p. 7854-7861.

[8]. Smith J M, Wren J C, Odziemkovski M, et al. The electrochemical response of preoxidized Cu in aqueaes sulphide solution. J. Electrochem. Soc. Vol. 154 (2007) p. C431-C438.

[9]. Chen J, Qin Z, Shoesmith D W. Kinetics of corrosion film growth on $\mathrm{Cu}$ in neutral chloride solutions containing small concentrations of sulfide. J. Electrochem. Soc. Vol. 157 (2010) p. C338-C345.

[10]. Rosborg B, Kosec T, Kranjc A, et al. Electrochemical impedance spectroscopy of pure copper exposed in bentonite under oxic conditions. Electrochim. Acta. Vol. 56 (2011) p. 7862-7870. 
[11]. Saleem M, Essa M H, Chakrabarti M H, et al. An Economical Means for Remediating a Multiple-Metal Contaminated Soil Using Electro-Kinetic Technology Under Natural Conditions. Int. J. Electrochem. Sci. Vol. 7 (2012) p. 7809-7822.

[12]. Wang Y, Lu Z, Li Y, Corrosion behavior of $\mathrm{Cu}$ and $\mathrm{Al}$ in western inland salty soil. Journal of Chinese Society for Corrosion and Protection, Vol. 25 (2005) p. 303-306.

[13]. Chen J, Qin Z, Shoesmith D W. Rate controlling reactions for copper corrosion in anaerobic aqueous sulphide solutions. Corros. Eng. Sci. Tech. Vol. 46 (2011) p. 138-141.

[14]. Smith J M, Qin Z, King F, et al. Sulfide film formation on copper under electrochemical and natural corrosion conditions. Corrosion. Vol. 63 (2007) p. 135-144.

[15]. Johan M R, Suan M S M, Hawari N L, et al. Annealing Effects on the Properties of Copper Oxide Thin Films Prepared by Chemical DepositionInt. J. Electrochem. Sci. Vol. 6 (2011) p. 6094-6104.

[16]. Wan Y, Wang X, Sun H, et al. Corrosion Behavior of Copper at Elevated Temperature. Int. J. Electrochem. Sci. Vol. 7 (2012) p. 7902-7914. 